\title{
PENGARUH PROSES PEREBUSAN DAN PENGUKUSAN TERHADAP KANDUNGAN ALBUMIN DAN PROKSIMAT IKAN GABUS (Channa striata)
}

\author{
The Effect of The Boiling and Steaming Process on The Content of Albumin and Proximate Snakehead Fish (Channa \\ striata).
}

\author{
Siti Salmatia1* ${ }^{*}$ Kobajashi T. Isamu ${ }^{1}$, Ari Sartinah ${ }^{2}$ \\ 1Jurusan Teknologi Hasil Perikanan, Fakultas Perikanan dan IImu Kelautan Universitas Halu Oleo, Kendari, \\ Sulawesi Tenggara, Indonesia \\ 2Jurusan Farmasi, Fakultas Farmasi Universitas Halu Oleo, Kendari, Sulawesi Tenggara, Indonesia \\ *Email korespondensi: fianishani@gmail.com (Telp: +6282291371337) \\ Diterima: 27 Juni/ Disetujui 10 Februari 2020
}

Cara sitasi: Salmatia S, Isamu KT, Sartinah A. 2020. Pengaruh proses perebusan dan pengukusan terhadap kandungan albumin dan proksimat ikan gabus (Channa striata). Jurnal Fish Protech. 3(1):67-73.

\section{ABSTRACT}

The aim of this study was to determine the effect of the boiling and steaming process on the content of albumin and proximate snakehead fish (Channa striata). This study used a complete randomized design (CRD) consisting of 3 treatments, namely: $P 1=$ fresh, $P 2=$ boiled and $P 3=$ steamed and each treatment was repeated three times to obtain 9 experimental units. The data obtained were analyzed using analysis of variance (ANOVA), if the results of the analysis showed significant differences, then the Duncan's Multiple Range Test (DMRT) was performed to determine the real difference between treatments with a confidence level of $95 \%(\alpha=0.05)$. The results obtained showed that the effect of boiling and steaming processes on cork fish albumin levels were observed to have a significant effect where the value of albumin levels at $P 1$ produced albumin levels was $0,35 \mathrm{mg} / \mathrm{ml}, P 2$ was $0,24 \mathrm{mg} / \mathrm{ml}$ and $P 3$ was $0,27 \mathrm{mg} / \mathrm{ml}$. Proximate analysis value on water content and protein content produced has a very significant effect, where the highest value of water content is in P2 of 76,25\% and the highest value of protein content is in P2 of $21,52 \%$ and in proximate analysis of ash content and fat content snakehead fish has a significant effect where the highest value of ash content is in P3 of 1,2\% and the highest value of fat content is in P1 of 1,79\%.

Keywords: albumin, snakehead fish, boiling, steaming.

\begin{abstract}
ABSTRAK
Tujuan penelitian ini adalah untuk mengetahui pengaruh proses perebusan dan pengukusan terhadap kandungan albumin dan proksimat ikan gabus (Channa striata). Penelitian ini menggunakan rancangan acak lengkap (RAL) yang terdiri dari 3 perlakuan, yaitu : $\mathrm{P} 1$ = segar, $\mathrm{P} 2$ = rebus dan $\mathrm{P} 3$ = kukus dan masing-masing perlakuan diulang sebanyak tiga kali sehingga diperoleh 9 unit percobaan. Data yang diperoleh dianalisis menggunakan analisis ragam (ANOVA), jika hasil analisis menunjukan beda nyata maka dilakukan uji Duncan's Multiple Range Test (DMRT) untuk mengetahui beda nyata antar perlakuan dengan tingkat kepercayaan $95 \%(\alpha=0,05)$. Hasil penelitian yang diperoleh menunjukkan bahwa pengaruh proses perebusan dan pengukusan terhadap kadar albumin ikan gabus yang diamati berpengaruh nyata dimana nilai kadar albumin pada P1 kadar albumin yang dihasilkan sebesar $0,35 \mathrm{mg} / \mathrm{ml}, \mathrm{P} 2$ sebesar $0,24 \mathrm{mg} / \mathrm{ml}$ dan P3 sebesar $0,27 \mathrm{mg} / \mathrm{ml}$. Nilai analisis proksimat pada kadar air dan kadar protein yang dihasilkan berpengaruh sangat nyata, dimana nilai tertinggi kadar air terdapat pada P2 sebesar $76,25 \%$ dan nilai tertinggi kadar protein terdapat pada P2 sebesar $21,52 \%$ dan pada analisis proksimat kadar abu dan kadar lemak ikan gabus berpengaruh nyata dimana nilai tertinggi kadar abu terdapat pada P3 sebesar 1,2\% dan nilai tertinggi kadar lemak terdapat pada P1 sebesar 1,79\%.
\end{abstract}

Kata kunci: Albumin, lkan gabus, perebusan, pengukusan. 


\section{PENDAHULUAN}

Indonesia adalah negara kepulauan yang mempunyai potensi cukup besar sebagai sumber daya perikanan. Perairan di Indonesia terdiri dari Perairan laut dan perairan darat (Ratna et al., 2011 dalam Sarnia et al., 2018). Sulawesi Tenggara merupakan salah satu provinsi di Indonesia yang memiliki potensi ikan air tawar yang cukup besar. Potensi budidaya ikan air tawar yang dimiliki Sulawesi Tenggara adalah sebesar 31.231 hektar (Ditjen Budidaya Kementerian Kelautan dan Perikanan, 2014). Data produksi perikanan tangkap ikan gabus meningkat pada setiap tahunnya, yaitu tahun 2008 yaitu 29.842 ton, 34.017 ton tahun 2010 dan 40.790 ton pada tahun 2012 (KKP, 2015).

Ikan gabus (Channa striata) merupakan salah satu komoditas perikanan air tawar Indonesia yang memiliki kandungan protein tinggi, terutama karena protein albumin yang terkandung di dalamnya dan berpotensi sebagai biofarmaka (Moedjiharto, 2007). Protein mempunyai fungsi khas yang tidak dapat digantikan oleh zat gizi lain, yaitu membangun serta memelihara sel-sel jaringan tubuh (Almatsier, 2004).

Mustafa et al. (2013), dalam penelitiannya menemukan ikan gabus mengandung $\mathrm{Cu}, \mathrm{Fe}, \mathrm{Ca}$ dan Zn. Suprayitno (2003), menjelaskan bahwa ikan gabus jenis C. striata sangat kaya akan sumber albumin, salah satu jenis protein penting yang diperlukan tubuh manusia setiap hari. Sumber albumin ikan gabus sangat baik digunakan bagi penderita hipoalbumin (rendah albumin) dan penyembuhan luka pasca operasi maupun luka bakar bahkan masyarakat setempat sejak dahulu telah mengetahui manfaat ikan gabus untuk mempercepat proses penyembuhan sehingga biasanya wanita dianjurkan mengkonsumsi ikan gabus pasca melahirkan atau pasca khitanan anak laki-laki. Menurut Ulandari et al. (2011), ikan gabus memiliki manfaat antara lain meningkatkan kadar albumin dan daya tahan tubuh, mempercepat proses penyembuhan luka dalam atau luka luar.

Protein ikan gabus diduga mempunyai aktivitas penghambatan terhadap ACE (angiotensin-converting enzyme) yang digunakan untuk menghambat terjadinya hipertensi, pendugaan tersebut didukung oleh hasil penelitian Nahariah et al. (2014) yang menunjukkan protein albumin pada putih telur memiliki potensi sebagai antihipertensi. Aktivitas antihipertensi pada protein albumin pada putih telur tersebut adalah $13,55 \%$ pada telur ayam kampung, telur itik $12,77 \%$ dan telur ayam ras petelur 7,23\%. Ram et al. (2011) menyatakan bahwa ikan gabus memiliki kandungan asam lemak yaitu EPA, DHA, asam arakidonat, asam palmitat. Dahlan et al. (2010) menyatakan bahwa ikan gabus juga memiliki kandungan asam amino yang lengkap seperti fenilalanin, isoleusin, leusin, metionin, valin, arginin, glisin, alanin, prolin, serin, sistein, tirosin, treonin, histidin, lisin, glutamat dan asam aspartat.

Penelitian terdahulu telah banyak dilakukan untuk mengetahui kandungan albumin dari ikan gabus dengan metode-metode pengolahan yang berbeda yaitu dengan metode pengasapan, ekstraksi, dan lain sebagainya seperti pada penelitian Alfarisy et al. (2013) yaitu ekstrak ikan gabus sebanyak $4,5 \mathrm{~kg}$ menghasilkan rendemen sebanyak $10,44 \%$ atau 470 $\mathrm{ml}$ albumin, Sulthoniyah et al. (2013) dalam penelitiannya tentang pengaruh suhu pengukusan terhadap kandungan gizi dan organoleptik abon ikan gabus menghasilkan nilai kadar albumin sebanyak $1,1254 \%$ pada perlakuan terbaik yaitu pada suhu $50^{\circ} \mathrm{C}$ tetapi pengolahan dengan metode pemanasan yang biasa dilakukan pada umumnya seperti perebusan dan pengukusan masih jarang ditemukan sehingga perlu dilakukan penelitian tentang pengaruh proses perebusan dan pengukusan terhadap kandungan albumin dan proksimat ikan gabus.

\section{METODE PENELITIAN}

\section{Alat dan Bahan}

Alat yang digunakan pada penelitian ini adalah kompor, panci atau dandang, pisau, baskom, termometer, blender (Miyako), tabung reaksi (Iwaki), gelas ukur (Iwaki), gelas piala (Iwaki), labu ukur, batang pengaduk, pipet ukur (Iwaki), pipet mikro (Fisherbrand Elite), botol reagen, rak tabung reaksi, tabung sentrifuge (Greiner), filler, timbagan analitik, 
Stopwatch, sentrifuge (Eppendorf), spektrofotometer Visibel (Japan Apel PD-3000 UV).

Bahan yang digunakan pada penelitian ini adalah ikan gabus segar, air, Buffer fosfat, Rancangan Penelitian

Rancangan yang digunakan dalam penelitian ini adalah Rancangan Acak Lengkap (RAL) dengan 3 perlakuan yaitu P1 (segar), P2 (rebus), dan P3 (kukus), dan masing-masing perlakuan diulang sebanyak 3 kali sehingga diperoleh 9 unit percobaan.

\section{Prosedur Penelitian}

\section{Penyiapan Bahan Baku}

Ikan gabus segar diperoleh dari penjual ikan di pasar Korem, Kelurahan Mandonga. Jarak antara pengambilan bahan baku dengan tempat diolahnya bahan baku adalah kurang lebih 20 menit perjalanan, menggunakan motor sebagai kendaraan dengan kecepatan rata-rata yang digunakan adalah 40 $\mathrm{km} / \mathrm{jam}$. Ikan gabus yang diperoleh adalah ikan yang masih hidup, sehingga saya menggunakan kantong plastik berisi air sebagai wadah penyimpanan bahan baku selama perjalanan dan setelah tiba dilokasi pengolahan, bahan baku langsung dipreparasi kemudian diolah sesuai perlakuan yaitu direbus dan dikukus.

\section{Proses Pengolahan}

a. Preparasi lkan Gabus

Ikan gabus yang masih hidup dimatikan dengan cara ditusuk bagian kepala ikan gabus menggunakan

\section{HASIL DAN PEMBAHASAN}

Analisis kadar albumin dan proksimat pada penelitian ini bertujuan untuk mengetahui kandungan albumin dan proksimat (air, abu, lemak dan protein) yang terdapat pada ikan gabus dengan proses
$\mathrm{CuSO}_{4} .5 \mathrm{H}_{2} \mathrm{O}$ (Tembaga sulfat Kristal), $\mathrm{NaKC}_{4} \mathrm{H}_{4} \mathrm{O}_{6} .4 \mathrm{H}_{2} \mathrm{O}$ (Natrium Kalium Tartarat), $\mathrm{NaOH}$ $0,2 \mathrm{~N}$, Eter, Aquades, $\mathrm{Na}_{2} \mathrm{SO}_{3}$ (Natrium sulfit) $25 \%$ dan Bovine Serum Albumin (BSA).

pisau, kemudian disiangi atau dibuang bagian kepala, isi perut, sisik, sirip, ekor, dan insangnya. Setelah disiangi ikan dicuci sampai benar-benar bersih menggunakan air mengalir dan ditimbang, kemudian ikan diolah sesuai perlakuan yaitu direbus dan dikukus.

b. Perebusan

Pada proses perebusan, ikan gabus direbus menggunakan 1 liter air dalam panci stainless pada suhu $75^{\circ} \mathrm{C}$ selama 20 menit.

c. Pengukusan

Pada proses pengukusan, ikan gabus dikukus dalam dandang atau panci stainless pada suhu $75^{\circ} \mathrm{C}$ selama 20 menit.

\section{Parameter Uji}

Analisis kadar albumin (Sari et al., 2017), analisis proksimat meliputi kadar air (AOAC, 2005), kadar abu (AOAC, 2005), kadar lemak (AOAC, 2005) dan kadar protein (AOAC, 2005).

\section{Analisis Data}

Data yang diperoleh dianalisis menggunakan analisis ragam (ANOVA), jika hasil analisis menunjukan beda nyata maka dilakukan uji Duncan's Multiple Range Test (DMRT) untuk mengetahui beda nyata antar perlakuan dengan tingkat kepercayaan $95 \%(\alpha=0,05)$. Data diolah menggunakan aplikasi Microsoft Exel (2007).

\section{Uji sensori}

pengolahan yang berbeda. Adapun kandungan albumin dan proksimat ikan gabus dapat dilihat pada Tabel 1 dan 2 dibawah ini. 
Tabel 1. Rerata nilai kadar albumin ikan gabus

\begin{tabular}{ccc}
\hline Perlakuan & Rerata kadar albumin $(\mathrm{mg} / \mathrm{ml}) \pm$ SD & DMRT $_{0,05}$ \\
\hline P1 & $0,35^{\mathrm{b}} \pm 0,01$ & \\
P2 & $0,24^{\mathrm{a}} \pm 0,01$ & $2=0,03$ \\
P3 & $0,27^{\mathrm{a}} \pm 0,03$ & $3=0,04$ \\
\hline
\end{tabular}

Tabel 2. Rerata nilai kadar proksimat ikan gabus

\begin{tabular}{ccccc}
\hline Perlakuan & \multicolumn{4}{c}{ Parameter (\%) \pm SD } \\
\cline { 2 - 5 } & Air & Abu & Lemak & Protein \\
\hline P1 & $73,44^{\mathrm{b}} \pm 0,2$ & $0,91^{\mathrm{a}} \pm 0,02$ & $1,79^{\mathrm{b}} \pm 0,02$ & $19,19^{\mathrm{a}} \pm 0,04$ \\
P2 & $76,2^{\mathrm{c}} \pm 0,3$ & $0,91^{\mathrm{a}} \pm 0,02$ & $1,79^{\mathrm{b}} \pm 0,02$ & $21,52^{\mathrm{b}} \pm 0,1$ \\
P3 & $67,64^{\mathrm{a}} \pm 0,2$ & $1,2^{\mathrm{b}} \pm 0,07$ & $1,73^{\mathrm{a}} \pm 0,02$ & $21,28^{\mathrm{c}} \pm 0,03$ \\
\hline
\end{tabular}

Keterangan: Angka yang diikuti notasi huruf yang berbeda pada kolom yang sama menunjukkan berbeda nyata $(P<0,05)$

\section{Uji Kadar Albumin}

Berdasarkan data pada Tabel 1 , hasil analisa menunjukan bahwa pengaruh proses perebusan dan pengukusan terhadap kadar albumin berbeda nyata. Hasil tersebut didapatkan bahwa nilai kadar albumin berkisar antara 0,35-0,24 $\mathrm{mg} / \mathrm{ml}$. Nilai rerata kadar albumin tertinggi yaitu $0,35 \mathrm{mg} / \mathrm{ml}$ pada perlakuan $\mathrm{P} 1$. Kandungan albumin dalam penelitian ini tergolong rendah karena kandungan albumin dalam tubuh ikan gabus adalah sebesar $1,7412 \mathrm{mg} / 100 \mathrm{~g}$ daging (Sadjudin, 2015).

Tingginya kadar albumin ikan gabus segar disebabkan karena ikan gabus segar tidak mengalami proses pemasakan atau kontak langsung dengan panas sehingga kadar albuminnya tetap terjaga. Stryer (1968), Slavik (1982) dan Arakawa et al. (1991) dalam Folawiyo and Apenten (1996), menjelaskan bahwa perlakuan panas pada albumin akan menghasilkan perubahan struktur yang tidak dapat balik (irreversible), yang terlihat dengan meningkatnya protein yang tidak larut dalam air. Nilai rerata terendah yaitu $0,24 \%$ pada perlakuan $\mathrm{P} 2$.

Rendahnya nilai kadar albumin pada perlakuan P2 diduga dipengaruh oleh proses pengolahan karena air yang digunakan pada proses perebusan bersentuhan langsung dengan daging ikan. Penurunan nilai kadar albumin pada ikan gabus disebabkan karena adanya suhu dengan waktu pemanasan yang lama sehingga dapat merusak struktur kimia dari albumin. Menurut De Man (1997), bahwa albumin mempunyai sifat yang dapat terjadi koagulasi protein dan denaturasi selama pemanasan dengan rentang suhu sekitar $55-75^{\circ} \mathrm{C}$.

\section{Analisis Proksimat}

\section{Kadar Air}

Berdasarkan data pada Tabel 2, menunjukan bahwa pengaruh proses perebusan dan pengukusan terhadap kadar air berbeda sangat nyata. Hasil tersebut diketahui bahwa hasil penilaian proksimat terhadap parameter kadar air berkisar antara 76,44\%$67,64 \%$. Nilai rerata kadar air tertinggi yaitu $76,44 \%$ pada perlakuan P2. Tingginya kadar air ikan gabus diduga karena proses perebusan dimana pemanasan dengan cara menggunakan air dan suhu yang tinggi dapat meningkatkan kadar air ikan gabus sehingga komponen air lebih melembab pada daging ikan gabus sehingga semakin banyak air yang digunakan dan tinggi suhu saat perebusan maka semakin tinggi kadar air pada ikan gabus. Hal ini sesuai dengan peryataan (Sulthoniyah et al., 2013), bahwa proses pemasakan dengan suhu yang semakin tinggi menyebabkan ikatan antara komponen bahan pangan pecah sehingga air akan berikatan dengan bahan tersebut dan menyebabkan kadar airnya meningkat. Sedangkan nilai rerata yang terendah terdapat pada perlakuan P3 yakni 67,64\%.

Rendahnya nilai kadar air ikan gabus diduga karena proses pengukusan yang menggunakan 
pemanasan dengan uap panas dan pada proses pengukusan daging ikan gabus tidak persentuhan langsung dengan air yang digunakan, sehingga komponen air pengukusan kurang melembab pada daging ikan gabus. Menurut Fatmawati dan Mardiana (2014), komponen air pada proses pengukusan tidak bersentuhan langsung dengan daging ikan sehingga air pada daging ikan menguap menjadi cairan, selain itu diketahui bahwa rendahnya nilai kadar air ikan gabus berkaitan dengan menurunnya rehidrasi jaringan ikat daging ikan gabus, sebagai akibat meningkatnya suhu dan lama pengukusan, pada kondisi rehidrasi menurun, kondisi kemampuan daging menahan air hilang karena ruang antar jaringan ikat daging mengkerut dan berkurang volumenya, sehingga air dalam daging menguap dan keluar sebagai cairan (Nugroho, 2013).

\section{Kadar Abu}

Berdasarkan data pada Tabel 2, hasil analisa menunjukan bahwa pengaruh proses perebusan dan pengukusan terhadap kadar abu ikan gabus berbeda nyata. Hasil tersebut didapatkan bahwa nilai proksimat terhadap parameter kadar abu berkisar antara 1,2\%$0,91 \%$. Nilai rerata kadar abu tertinggi yaitu $1,2 \%$ pada perlakuan P3. Tingginya kadar abu ikan gabus diduga karena daging ikan gabus mengalami perubahan saat proses pengukusan dan pengurangan air selama pemanasan. Hal ini sesuai dengan pernyataan Saraswati (2013), bahwa perubahan kadar abu pada ikan yang telah dikukus berkaitan dengan penurunan kadar air yang terjadi setelah pengukusan. Devi dan Sarojnalini (2012), menyatakan bahwa peningkatan kadar abu juga dapat dipengaruhi oleh karakteristik ikan karena ikan yang memiliki banyak tulang menyediakan mineral dengan jumlah yang lebih banyak setelah dimasak dibandingkan dengan pada kondisi mentah.

Nilai rerata yang terendah yaitu $0,91 \%$ pada perlakuan P1 dan P2. Rendahnya kesamaan nilai P1 dan P2 diduga karena kadar abu yang dihasilkan pada ikan gabus segar dan rebus merupakan hasil dari kandungan mineral alami pada ikan gabus. Hal ini sesuai pernyataan Suprayitno (2006), bahwa ikan gabus juga mengandung mineral zinc, dan mineral lain seperti besi, kalsium dan posfor, selain itu kadar abu pada perebusan ikan gabus dapat menurun.

\section{Kadar Lemak}

Berdasarkan data pada Tabel 2, hasil analisa menunjukan bahwa pengaruh proses perebusan dan pengukusan terhadap kadar lemak berbeda nyata. Hasil tersebut didapatkan bahwa nilai proksimat terhadap parameter kadar lemak berkisar antara $1,79 \%-1,73 \%$. Nilai rerata kadar lemak tertinggi yaitu $1,79 \%$ pada perlakuan P1. Tingginya kadar lemak ikan gabus diduga karena ikan segar tidak mengalami penyusutan kadar lemak karena proses perebusan atau pengukusan, selain itu ikan gabus diketahui sebagai ikan segar yang memiliki kadar lemak sedang. Hal ini didukung oleh pernyataan Adawyah (2008), bahwa ikan berkadar lemak sedang untuk ikan dengan kadar lemak 0,5-2\%. Puwastien et al. (1999), menyatakan kadar lemak pada ikan dipengaruhi oleh musim dan lokasi geografis. Ikan yang hidup di perairan tropis cenderung memiliki kadar lemak yang rendah.

Nilai rerata yang terendah yaitu $1,73 \%$ pada perlakuan P3. Rendahnya nilai kadar lemak pada ikan gabus kukus diduga karena ikan gabus mengalami menyusutan kadar lemak saat pengukusan, semakin ikan gabus dikukus semakin berkurang kadar lemak ikan tersebut. Hal ini sesuai dengan hasil penelitian Devi dan Sarojnalini (2012), terjadi penyusutan kadar lemak pada daging ikan dari 5,83\% (ikan segar) menjadi $1,4 \%$ setelah proses pengukusan. Dhanapal et al. (2012), menyatakan bahwa penyusutan kadar lemak pada ikan yang telah mengalami proses pengukusan terutama disebabkan oleh hilangnya cairan jaringan selama proses pemasakan. Pemasakan mempercepat gerakan molekul-molekul lemak sehingga jarak antar molekul menjadi besar dan mempermudah proses pengeluaran lemak (Saraswati, 2013).

\section{Kadar Protein}

Berdasarkan data pada Tabel 2, hasil analisa menunjukkan bahwa pengaruh proses perebusan dan pengukusan terhadap kadar protein berbeda sangat nyata. Hasil tersebut didapatkan bahwa nilai proksimat terhadap parameter kadar protein berkisar antara 
$21,52 \%-19,19 \%$. Nilai rerata kadar protein tertinggi adalah $21,52 \%$ pada perlakuan P2. Tingginya nilai kadar protein diduga karena ikan gabus rebus menunjukkan struktur daging ikan gabus yang lebih kompak dan rapat dibandingkan pada struktur daging ikan gabus sebelum proses perebusan, sehingga semakin dilakukan pemasakan maka kadar protein semakin meningkat. Hal ini sesuai dengan penelitian Puwastien et al. (1999), bahwa kadar protein ikan berubah secara proporsional dari 18,1\% pada kondisi segar menjadi 22,9\% setelah pemasakan.

Selain itu kadar protein pada ikan gabus terjadi penyusutan kadar air saat perebusan. Devi dan Sarojnalini (2012), menyatakan bahwa perubahan kadar protein pada ikan berkaitan dengan penyusutan kadar air pada ikan selama proses pemasakan. Hal tersebut juga didukung oleh pernyataan Saraswati (2013), semakin besar penyusutan kadar air pada ikan setelah pemasakan, semakin besar pula perubahan kadar protein pada ikan

Rendahnya nilai P1 diduga karena ikan segar tidak dilakukan pemasakan, sehingga kadar protein ikan gabus menjadi tetap dan tidak meningkat bahkan mengalami penurunan mutu selama penyimpanan. Hal ini menunjukkan tanpa pemasakan atau perebusan ikan gabus tidak mampu menghambat

\section{DAFTAR PUSTAKA}

Adawyah R. 2008. Pengolahan Dan Pengawetan Ikan. Jakarta: Pt Bumi Aksara

Alfarisy MU, Abdulgani N dan Ulfin I. 2013. Pengaruh Jenis Kelamin dan Ukuran terhadap Kadar Albumin pada Ikan Gabus (Channa striata). Jurnal Sains dan Seni Pomits Vol. 2, No.1. 2337-3520

Almatsier S. 2004. Prinsip Dasar IImu Gizi. Gramedia Pustaka Utama, Jakarta.

(AOAC) Association of Official Analytical Chemists. 2005. Official Methods of Analysis of The Association of Official Agriculture Chemist 16th Edition. Virginia.

Dahlan DCK, Matjais AM, Ahmad Z, Md AA, and Adam A. 2010. Amino and Fatty Acids Composition in Haruan Traditional Extract. Boletin Latino-americano y del Caribe de proses penurunan mutu ikan gabus segar. Menurut Sutoyo dalam Kadir (2004), lamanya penyimpanan akan memberikan pengaruh terhadap kualitas fisik dan kimia ikan gabus sehingga menyebabkan nilai organoleptik dan kadar protein menjadi menurun.

\section{KESIMPULAN}

Berdasarkan hasil penelitian, dapat disimpulkan sebagai berikut:

1. Pengaruh proses perebusan dan pengukusan terhadap kadar albumin ikan gabus yang diamati berpengaruh nyata dimana pada P1 kadar albumin yang dihasilkan sebesar $0,35 \mathrm{mg} / \mathrm{ml}$, P2 sebesar $0,24 \mathrm{mg} / \mathrm{ml}$ dan P3 sebesar $0,27 \mathrm{mg} / \mathrm{ml}$.

2. Pengaruh proses perebusan dan pengukusan terhadap analisis proksimat kadar air dan kadar protein ikan gabus berpengaruh sangat nyata, dimana nilai tertinggi kadar air terdapat pada P2 sebesar $76,25 \%$ dan nilai tertinggi kadar protein terdapat pada P2 sebesar $21,52 \%$ dan pada analisis proksimat kadar abu dan kadar lemak ikan gabus berpengaruh nyata dimana nilai tertinggi kadar abu terdapat pada P3 sebesar 1,2\% dan nilai tertinggi kadar lemak terdapat pada P1 sebesar $1,79 \%$
Plantas Medicinales y Aromaticas, 9(5), 414429.

De Man, J.M. 1997. Kimia Pangan. Edisi 2. Penerbit Institut Teknologi Bandung.

Devi W and Sarojnalini C. 2012. Impact of Different Cooking Methods on Proximate and Mineral Composition of Amblypharyngodon Mola of Manipur. International Journal Of Advanced Biological Research 2(4): 641-645.

Dhanapal K, Reddy VS, Naik BB, Venkateswarlu G, Reddy AD and Basu S. 2012. Effect of Cooking on Physical, Biochemical, Bacteriological Characteristics and Fatty Acid Profile of Tilapia (Oreochromis Mossambicus) Fish Steaks. Archives of Applied Science Research 4(2): 1142-1149. 
Ditjen Budidaya Kementerian Kelautan dan Perikanan. 2014. Data dan Laporan Statistik Perikanan Budidaya. Jakarta.

Fatmawati dan Mardiana. 2014. Tepung Ikan Gabus sebagai Sumber Protein (Food Supplement). Jurnal Bionature, 15: 54-60

Folawiyo YL and Apenten ORK. 1996. The Effect of Heat Acid Treatment on the Structure of Rapeseed Albumin (Napin). J. Food Sci. 61: 237-239.

Kadir L. 2004. Pengaruh Suhu dan Lama Penyimpanan terhadap Jumlah Kandungan Bakteri dan Kualitas Fisik Ikan Tongkol Asap (Euthynnus Afinis). Jbp 6: 79-84.

[KKP] Kementrian Kelautan dan Perikanan. 2015. Data Produksi Perikanan Tangkap. www.kkp.go.id. [27 maret 2019].

Mustafa A, Sujuti H, Permatasari N and Widodo MA. 2013. Determination of Nutrient and Amino Acid Composition of Pasuruan Channa striata Extract. International Journal of Science and Technology, 1(2):63-71

Moedjiharto TJ. 2007. Ikan sebagai Bahan Substitusi Human Serum Albumin (HSA) dalam Penyumbang Biofarma Indonesia. http://www.old-prasetya.ub.id. [28 April 2019].

Nahariah, Anang ML, Effendi A, Antonius H, Priyo B, dan Yoyok BP. 2014. Evaluasi Potensi Aktivitas ACE-inhibitor Endogenous pada Putih Telur dari Jenis Unggas yang Berbeda. Jurnal Fakultas Peternakan dan Pertanian. 1: 207213.

Nugroho M. 2013. Isolasi Albumin dan Karakterisasi

Berat Molekul Hasil Ekstraksi secara Pengukusan Ikan Gabus (Ophiocephalus Striatus). Jurnal Saintek Perikanan. 9(1): 40-49 Puwastien P, Judprasong K, Kettwan E, Vasanachitt $K$, Nakngamanong $Y$ and Bhattacharjee $L$. 1999. Proximate Composition of Raw and Cooked Thai Fresh Water and Marine Fish. Journal of Food Composition and Analysis 12(3): 9- 16

Ram JA, Ishak AD, Enyu $Y$, Kuah MK, Wong $K$ and Shu-Chien AC. 2011. Molecular Cloning and
Ontogenic mRNA Expression of Fatty Acid Desaturase in the Carnivorous Striped Snakehead Fish (Channa striata). Comparative Biochemistry and Physiology a Molecular and Integral Physiology. 158(4): 415-422.

Sadjudin HR. 2015. Manfaat Ikan Gabus, Sumber Protein

Penyembuh Penyakit. https://www.google.co m/amp/s/www.mongabay.co.id/2015/03/18/ma nfaat-ikan-gabus-sumber-protein-tinggipenyembuh-penyakit/amp/. [04 Januari 2020]

Saraswati A. 2013. Efek Pengukusan terhadap Kandungan Asam Lemak dan Kolesterol Kakap Merah (Lutjanus Bohar). Departemen Teknologi Hasil Perairan Fakultas Perikanan dan IImu Kelautan Institut Pertanian Bogor.

Sari FA, Handayani S dan Nurhaini R. 2017. Pengaruh Penetapan Kadar Albumin dalam Ikan Gabus (Channa striata) Kukus dengan Metode Spektrofotometri Visibel. CERATA Journal of Pharmacy Science. 6 (2) : 8-17.

Sarnia, Ibrahim MN dan Isamu KT. 2018. Karakteristik Ikan Gabus (Channa striata) Asap dari Produsen yang Berbeda di Kabupaten Konawe Sulawesi Tenggara. Jurnal Fakultas Perikanan 1(1). ISSN 2621-1475.

Sulthoniyah TS, Sulistiyati DT dan Suprayitno E. 2013. Pengaruh Suhu Pengukusan terhadap Kandungan Gizi dan Organoleptik Abon Ikan Gabus (Ophiocephalus Striatus). Thpi Student Journal. I (1) : 33-45

Suprayitno E. 2003. Albumin Ikan Gabus (Ophiocepalus striatus) sebagai Makanan Fungsional Mengatasi Gizi Masa De pan. http://www.antarajati.com $\quad(30 \quad$ April 2019).

2006. Potensi Serum Albumin dari Ikan Gabus. Kompas. Cybermedia.

Ulandari A, Kurniawan D dan Putri AS. 2011. Potensi Protein Ikan Gabus dalam Mencegah Kwashiorkor pada Balita di Provinsi Jambi. Universitas Jambi. 